\title{
Non-operating Room Anaesthesia Practices in an Endoscopy Unit at a Tertiary Centre: A Retrospective Evaluation
}

\author{
Tersiyer Bir Merkezde Endoskopi Ünitesinde Ameliyathane Dışı Anestezi \\ Uygulamaları: Retrospektif Değerlendirme
}

\author{
(1) Ayșe Gül Ferlengez¹, (1) Ekrem Çakar2, (1) Duygu Demiröz Aslan1 \\ 1 University of Health Science Turkey, İstanbul Training and Research Hospital, Clinic of Anaesthesiology and Reanimation, İstanbul, Turkey \\ 2University of Health Science Turkey, İstanbul Training and Research Hospital, Clinic of General Surgery, İstanbul, Turkey
}

\begin{abstract}
Introduction: In recent years, gastrointestinal endoscopic procedures have been performed with sedo-analgesia at many centres. We aimed to present a 1-year retrospective analysis of non-operating room anaesthesia (NORA) applications at the endoscopy unit of our research and training hospital.

Methods: We retrospectively analysed the NORA applications at our endoscopy unit between 01.01.2018 and 31.12.2018. The gender, age, American Society of Anaesthesiologist (ASA) score, intervention, anaesthesia drugs and complications were retrospectively analysed for 18.291 patients.

Results: The sample comprised $47.03 \%$ men $(n=8,602)$ and $52,97 \%$ women $(n=9,689)$, with a mean age of $58.75 \pm 13.75$ years (range, 16-92 years). Per the ASA classification, there were $57.22 \%(n=10,467), 37.92 \%(n=6,936), 4.79 \%(n=876)$ and $0.07 \%$ $(n=12)$ patients with ASA grades I, II, III and IV, respectively. Gastroscopy ( $n=9,481,51.84 \%)$, followed by colonoscopy $(n=5,596,30.60 \%)$ were the most commonly performed procedures. The combination of midazolam and meperidine; propofol, midazolam and meperidine and midazolam alone were administered for $43.99 \%(n=8,046)$; $53.48 \%(n=9,782)$ and $2.54 \%(n=463)$ of the patients, respectively. In a patient with hypertension, no major complication was encountered except for pneumothorax during the endoscopic retrograde cholangiopancreatography. The most common significant complication was desaturation; seen in $3.05 \%$ of the patients $(\mathrm{n}=559)$.
\end{abstract}

Conclusion: Endoscopy units are non-operating units, albeit with a high patient volume. Thus, adopting sedation for interventional procedures in these units simplifies the procedure and increases patient safety and satisfaction, along with physician's comfort. Compared with the studies performed at our clinic, we found similar complication rates as with sedoanalgesia protocols.

Keywords: Endoscopy unit, non-operating room anaesthesia applications, sedation

\section{öZ}

Amaç: Son yıllarda birçok merkezde gastrointestinal sistem endoskopik ișlemleri sedo-analjezi ile yapılmaktadır. Çalıșmamızda bir eğitim ve araștırma hastanesinin endoskopi ünitesinde bir yıllık süreçte ameliyathane dıșı anestezi (ADA) uygulamalarına ait deneyimlerimizin retrospektif analizlerini sunmayı amaçladık.

Yöntemler: 01.01.2018 ve 31.12.2018 tarihleri arasında endoskopi ünitesindeki ADA uygulamalarımızı geriye dönük araștırdık. ADA uyguladığımız 18.291 hastanın cinsiyetleri, yașları, American Society of Anesthesiologist (ASA) skorları, yapılan girişimleri, uygulanan anestezi ilaçları ve komplikasyonları hasta dosyalarından geriye dönük incelendi.

Bulgular: Olguların cinsiyet dağılımı erkek/kadın 8.602

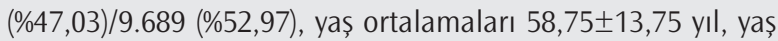
dağılımı 16-92 yaș arasındaydı. ASA sınıflaması ASA I 10.467 $(\% 57,22)$, ASA II $6.936(\% 37,92)$, ASA III $876(\% 4,79)$, ASA IV $12(\% 0,07)$ hasta şeklindeydi. En sık $9481(\% 51,84)$ olguyla gastroskopi ișlemi yapılmış olup bunu $5.596(\% 30,60)$ olgu ile kolonoskopi ișleminin takip ettiği görüldü. Olguların 8.046'sına $(\% 43,99)$ midazolam + meperidin kombinasyonu, 9.782'sine $(\% 53,48)$ propofol + midazolam + meperidin kombinasyonu ve 463 'üne $(\% 2,53)$ sadece midazolam sedasyonu uygulandığı tespit edildi. Hipertansiyonu olan bir hastada endoskopik retrograd kolanjiyopankreatografi ișlemi sırasında pnömotoraks gelișmesi dıșında major bir komplikasyonla karşılașılmadı. Minör komplikasyonlardan en sık $559(\% 3,05)$ olgu ile desatürasyon görüldüğü tespit edildi.

Sonuç: Endoskopi üniteleri sirkülasyonun hızlı olduğu ameliyathane dışı ünitelerdir. Bu ünitelerde girişimsel ișlemler sırasında hastalara verilen sedasyon; ișlemi kolaylaştırmakta, hem hasta güvenliğini ve memnuniyetini hem de hekim konforunu artırmaktadır. Kliniğimizde kullanılan sedo-analjezi protokollerinin yapılan çalıșmalarla karșılaștırıldığında komplikasyon oranlarının benzer olduğunu gördük.

Anahtar Kelimeler: Endoskopi ünitesi, ameliyathane dıșı anestezi uygulamaları, sedasyon 


\section{Introduction}

Along with the technological development, nowadays, interventional operations performed for diagnosis and treatment in endoscopy units have increased. Although the appropriate equipment and sufficient number of personnel are available in endoscopy units, which are frequently located outside the operating room, potential complications should always be considered. Non-operating room anesthesia (NORA) applications during the interventional procedures performed in these units; with sedation/analgesia techniques, it is important in terms of both patient comfort and safety and surgeon comfort by increasing the success of the procedure applied to the inactive patient (1).

Gastroscopy, colonoscopy, endoscopic retrograde cholangiopancreatography (ERCP), rectosigmoidoscopy, colon polypectomy, balloon dilatation, stent placement in strictures, percutaneous endoscopic gastrostomy (PEG), endoscopic mucosal resection (EMR), endoscopic ultrasound (EUS) and endoscopic rectal ultrasound (ERUS) are some of the procedures performed in endoscopy units.

In recent years, performing endoscopy procedures with anesthesia is preferred because of the priority of patient comfort and satisfaction and increasing the quality of the procedure (2). Demand for anesthesia in endoscopic procedures has increased (3). In our clinic, endoscopy procedures are performed under anesthesia except for contraindications and the patient refuse anesthesia. Anesthesiologist and anesthesia technician perform the anesthesia procedures.

In our study, we aimed to present our experience by retrospectively evaluating the demographic data of the patients who underwent diagnostic or therapeutic gastrointestinal endoscopic procedures between 01.01.2018 and 31.12.2018, the interventional procedures, anesthesia agents used and anesthesia complications.

\section{Methods}

After obtaining the approval of the Ethics Committee of University of Health Science Turkey, İstanbul Training and Research Hospital, dated 12.04.2019 with approval number of 1796, 18,500 interventional procedures performed with anesthesia in the endoscopy unit for one year between 01.01.2018 and 31.12.2018 were evaluated. Patient information was scanned retrospectively from the anesthesia files; therefore, written consent could not be obtained from the patients for our study. Patients' gender, age, American Society of Anaesthesiologist (ASA) scores, interventional procedures, sedation agents used, major and minor complications were analyzed. Two hundred nine patient files were excluded due to lack of data. Data of 18,291 patients were included in the study.

Our NORA equipment has been determined according to the NORA practices guide published by Turkish Society of Anesthesiology and Reanimation in 2015. In the endoscopy unit, which has five operation rooms, each room has an oxygen source, an aspirator, a laryngoscope, an ambu and a monitor that measures heart rate, arterial blood pressure and saturation. In addition, there is an emergency cabinet containing emergency resuscitation materials, a defibrillator and an anesthesia device in the unit. Each patient is examined preoperatively before the procedure and then an appropriate sedation method is planned. The sedation process is initiated after monitoring the patients whose written consent had taken, opening the arteries and administered $100 \%$ oxygen with the mask. In our clinic, which has a recovery room, patients are followed up using the Aldrete scoring (Table 1) after the procedure, and patients with a score of 9 and above are discharged with recommendations.

In our study, if the heart rate decreased $25 \%$ below normal and was treated with atropine, it was evaluated as bradycardia. Those whose spontaneous breathing fell below 12 per minute were recorded as respiratory depression. A decrease in oxygen saturation below $90 \%$ in the fingertip probe was accepted as desaturation. Patients with respiratory depression and desaturation were treated with maneuvers that stimulate breathing, changing the position of the head, using an airway, and oxygen support with a mask. Those whose recovery time exceeded 10 minutes were recorded as prolonged recovery time.

\section{Statistical Analysis}

The data were evaluated by the researchers using the Statistical Package for Social Sciences (SPSS) for Windows 21.0 statistical package program in computer environment. Descriptive statistics of numerical variables were given as mean \pm standard deviation, while categorical variables were expressed as frequency ( $n$ ) and percentage (\%).

\section{Results}

The information of 209 out of the 18,500 patients who were examined retrospectively from the patient files could not be reached due to the lack of registration. 18,291 cases were included in the study. The gender distribution of 18,291 patients was found as male/female 8,602/9,689. The age distribution of the cases was between 16 and 92 years while the

Table 1. Aldrete scoring

\begin{tabular}{|c|c|c|}
\hline & & Score \\
\hline \multirow{3}{*}{ Activity } & Can move all four extremities & 2 \\
\hline & Can move two extremities & 1 \\
\hline & $\begin{array}{l}\text { Cannot move extremities voluntarily or } \\
\text { by order }\end{array}$ & 0 \\
\hline \multirow{3}{*}{ Respiration } & Can breathe and cough & 2 \\
\hline & Dysdpneic or restricted breathing & 1 \\
\hline & Apneic & 0 \\
\hline \multirow{3}{*}{ Circulation } & $\begin{array}{l}\text { Blood pressure } \pm 20 \% \text { of the value before } \\
\text { anesthesia }\end{array}$ & 2 \\
\hline & $\begin{array}{l}\text { Blood pressure } \pm 21-49 \% \text { of the value } \\
\text { before anesthesia }\end{array}$ & 1 \\
\hline & $\begin{array}{l}\text { Blood pressure } \pm 50 \% \text { of the value before } \\
\text { anesthesia }\end{array}$ & 0 \\
\hline \multirow{3}{*}{ Consciousness } & Fully awake & 2 \\
\hline & Wakes up with calling & 1 \\
\hline & No response & 0 \\
\hline \multirow{3}{*}{ Oxygen saturation } & Saturation at room air $>92 \%$ & 2 \\
\hline & $\mathrm{O}_{2}$ is required to keep saturation $>92 \%$ & 1 \\
\hline & $<90 \%$ saturation with oxygen application & 0 \\
\hline
\end{tabular}


mean age was 58.75 \pm 13.75 . ASA classification was ASA I 10,467 patients, ASA II 6.936 patients, ASA III 876 patients, ASA IV 12 patients (Table 2).

When the interventional procedures performed are examined; it was observed that 9.481 patients had gastroscopy, 5.596 patients had colonoscopy, 1,239 patients had ERCP, 260 patients rectosigmoidoscopy, 494 patients polypectomy, 104 patients balloon dilatation, 52 patients stent placement, 169 patients PEG procedure, 70 patients EMR, 385 patients EUS, 441 patients ERUS (Table 3, Graphic 1).

\begin{tabular}{|l|l|}
\hline \multicolumn{2}{|c|}{ Table 2. Demographic data and ASA scores of the patients } \\
\hline & Number $\mathbf{n}(\%)$ \\
\hline Gender (F/M) & $9689(52.97 \%) / 8602(47.03 \%)$ \\
\hline ASA I & $10.467(57.22 \%)$ \\
\hline ASA II & $6,936(37.92 \%)$ \\
\hline ASA III & $876(4.79 \%)$ \\
\hline ASA IV & $12(0.07 \%)$ \\
\hline F/M: Female/Male, ASA: American Society of Anaesthesiologist
\end{tabular}

Table 3. Distribution of interventional operations

\begin{tabular}{|c|c|c|}
\hline Interventional operations & \multicolumn{2}{|c|}{ Total number of patients $\mathbf{n}(\%)$} \\
\hline Gastroscopy & \multicolumn{2}{|l|}{$9,481(51.84 \%)$} \\
\hline Colonoscopy & \multicolumn{2}{|l|}{$5,596(30.60 \%)$} \\
\hline ERCP & \multicolumn{2}{|l|}{$1,239(6.77 \%)$} \\
\hline Rectosigmoidoscopy & \multicolumn{2}{|l|}{$260(1.42 \%)$} \\
\hline Colon polypectomy & \multicolumn{2}{|l|}{$494(2.70 \%)$} \\
\hline Baloon dilatation & \multicolumn{2}{|l|}{$104(0.57 \%)$} \\
\hline Stent placement & \multicolumn{2}{|l|}{$52(0.28 \%)$} \\
\hline PEG & \multicolumn{2}{|l|}{$169(0.92 \%)$} \\
\hline EMR & \multicolumn{2}{|l|}{$70(0.38 \%)$} \\
\hline EUS & \multicolumn{2}{|l|}{385 (2.11\%) } \\
\hline ERUS & \multicolumn{2}{|l|}{$441(2.41 \%)$} \\
\hline \multicolumn{3}{|c|}{$\begin{array}{l}\text { ERCP: Endoscopic retrograde cholangiopancreatography, PEG: percutaneous endoscopic } \\
\text { gastrostomy, EMR: endoscopic mucosal resection, EUS: endoscopic ultrasound, ERUS: } \\
\text { endoscopic rectal ultrasound }\end{array}$} \\
\hline & & 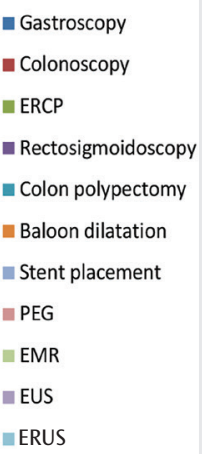 \\
\hline
\end{tabular}

Graphic 1. Distribution of interventional operations

ERCP: Endoscopic retrograde cholangiopancreatography, PEG: percutaneous endoscopic gastrostomy, EMR: endoscopic mucosal resection, EUS: endoscopic ultrasound, ERUS: endoscopic rectal ultrasound
When the anesthetic agents used in NORA applications were examined, it was seen that 8.046 were given a combination of midazolam + meperidine, 9,782 were given a combination of propofol + midazolam + meperidine, and 463 were given only midazolam (Table 4, Graphic 2).

When complications related to anesthesia were investigated during the procedures, no major complication was encountered except a patient with hypertension developed pneumothorax during the ERCP procedure. It was observed that 33 patients had respiratory depression, 47 patients had bradycardia, 559 patients had desaturation and 84 patients had delay in recovery time (Table 5).

\section{Discussion}

Endoscopy units are among the units where NORA is applied. NORA applications are special because they are far from the operating room and often with limited equipment, and they contain unique physical and clinical differences (1). In our study, it was observed that a total of 18,291 patients were given anesthesia at the endoscopy unit in one year.

All procedures to be performed for a patient preparing for general anesthesia also apply to patients who will undergo NORA. Karamnov et al. (4) reported that insufficient preoperative evaluation was responsible for more than $5 \%$ of patients who developed complications in NORA applications. Many studies have shown that a sufficient preoperative evaluation process reduces potential complications and the length of hospitalization $(5,6)$. In our clinic, patients are evaluated preoperatively before the procedure and are processed after necessary consultations.

\section{Table 4. Distribution of sedative agents used}

\begin{tabular}{|l|l|}
\hline Sedative used & Number $\mathbf{n}(\%)$ \\
\hline Midazolam + meperidine & $8,046(43.99 \%)$ \\
\hline Propofol + midazolam + meperidine & $9,782(53.48 \%)$ \\
\hline Midazolam & $463(2.53 \%)$ \\
\hline
\end{tabular}

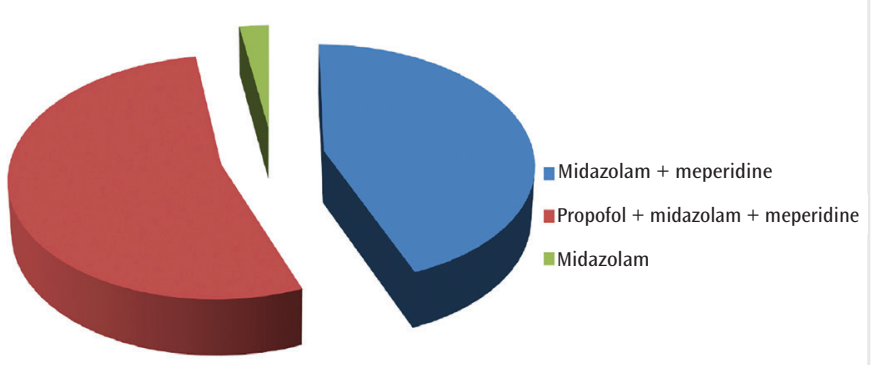

Graphic 2. Distribution of sedative agents used

\section{Table 5. Distribution of complications}

Complication

Pneumothorax

Respiratory depression

Bradycardia

Desaturation

Prolonged recovery time
Number of patients $\mathbf{n}(\%)$

1 (0.05\%)

$33(0.18 \%)$

$47(3.05 \%)$

$559(3.05 \%)$

$84(0.25 \%)$ 
In the preoperative evaluation of the patients, age and gender factors are first evaluated. Although age alone is not generally significant, it is taken into account in the selection of anesthesia method and depth. However, the rate of comorbidities that increase with age is of great importance $(7,8)$. In our study, it was observed that the mean age of the patients was $58.75 \pm 13.75$ and the female gender population was higher than that of men. ASA scoring is one of the important steps in terms of determining the risks that may develop during the procedure in advance and being prepared and informing the patient and/or patient relatives. Since comorbid diseases may increase with the increasing age, the ASA risk class may naturally increase (9). In our study, it was seen that there were ASA I 10,467 patients, ASA II 6,936 patients, ASA III 876 patients, and ASA IV 12 patients. The low mean age of the patients was associated with the high number of ASA I and II patients.

The preferred anesthetic agent and anesthesia method for the procedure differ between clinics. Anesthesia method varies depending on the duration of the procedure, degree of pain and complications. The patient's position, anxiety and stress rate, past experiences, allergy history and aspiration risk also play a determining role in the anesthesia method. Anesthetic drugs should be preferred considering the patient's condition, comorbidities and the effects of the drug on hemodynamic parameters (1). Conscious sedation method, in which the patient's spontaneous breathing continues, protective reflexes are maintained, and the desired response is obtained, is a common method. While mild sedation is preferred in the gastroscopy procedure, deeper sedation may be needed in other procedures. Deep sedation or general anesthesia is required in procedures such as EUS, which require the patient to stay still for a long time $(10,11)$. In our study, it was found that the preference for anesthesia was conscious sedation in gastroscopy cases, deep sedation was performed in procedures such as EUS, ERUS and ERCP, and general anesthesia was not needed in any of the cases.

The most commonly used agents in sedo-analgesia applications are propofol, ketamine, midazolam, dexmetomidine, fentanyl, meperidine and morphine (11). Midazolam, which has an amnesic effect, is the most commonly used sedative agent and is generally used in combination with propofol (12). Propofol, on the other hand, is preferred as a sedative due to its rapid recovery and antiemetic properties, but it is preferred to be used with other drugs because it does not have an analgesic effect and may cause complications such as loss of airway reflex, hypotension and bradycardia due to high dose use (13). There are studies reporting that the combined use of propofol and opioids reduces the incidence of nausea, vomiting and respiratory depression, which are side effects related to the use of high doses of opioids (14-17). According to metaanalysis data obtained from 36 randomized controlled studies, no significant difference was found between the efficacy and reliability of different sedation methods used in endoscopic procedures (18). In our study, it was observed that the combination of propofol + midazolam + meperidine was the most preferred anesthetic combination, and the second most preferred combination was midazolam + meperidine. We think that anesthesia method is chosen according to the procedure performed, the patient's age, additional diseases and sedation needs.

Different complication rates have been reported in NORA applications, with a rate of $6.2 \%$ in a study conducted with 3,583 patients, and $2.8 \%$ in another study with 1,622 patients $(19,20)$. There are also studies reporting complications with a rate of $0.17 \%$ (21). In our study, the complication rate was found to be $3.95 \%$ and minor complications were found to be the majority. It is noteworthy that our number of cases is quite high compared to other studies. We think that these differences in rates are due to differences in the number of patients, patient diversity and the procedures performed

Despite all preparations, complications may occur in NORA applications. These complications are aspiration, hypothermia, hypoxia, hypovolemia, hypotension, cardiac complications, anaphylaxis, nausea-vomiting, and procedure-related complications $(22,23)$. Metzner et al. (24) emphasized that the rate of death and aspiration pneumonia is more common in NORA applications than in the operating room. In our study, it was found that there were no complications related to death or aspiration in a one-year period. In the same study, it was stated that respiratory complications were more common in NORA applications (44\%) than in the operating room (24). In our study, 33 patients (0.18\%) had respiratory depression and 559 patients (3.05\%) had desaturation. In addition, pneumothorax developed in one patient due to the surgical procedure performed in our study and was treated with underwater chest tube drainage.

Complications of severe hypotension, arrhythmia, and myocardial ischemia can be seen in sedation of elderly ASA III and IV patients with severe comorbidities (25). In our study, bradycardia developed in 47 patients $(0.25 \%)$ and it was observed that they were treated with atropine. Other cardiac complications were not observed. We think that this result is due to the low rate of ASA III and IV patients in our study and the anesthetic management.

Many centers do not yet have recovery units for NORA applications. This situation causes the patients to be discharged without being recovered sufficiently and the number of cases to be taken during the day to be decreased $(26,27)$. Preventable respiratory complications mostly occur during recovery, so patients should be observed well until a complete recovery (28). There is a recovery room in the endoscopy unit of our hospital and patients with an Aldrete score of 9 or above are sent home. In our study, delay in recovery was observed in 84 patients in endoscopic procedures performed with sedo-analgesia. We think that it causes a delay in recovery after the procedure, depending on the comorbidities of the patients and the drugs and doses used.

Since our study was retrospective, randomization of the cases could not be achieved. For this reason, the number of patients between the groups is not equally distributed. The ages and ASA scores of the patients who underwent interventional procedures in our endoscopy unit differed according to the groups, and no comparison could be made between the anesthetic agent used and the rate of complications. There is a need for prospective, randomized studies with no difference in age groups regarding the NORA applications.

\section{Conclusion}

Anesthesia is required for different interventional procedures, especially gastroscopy, in endoscopy units outside the operating room. Sedation given to patients in these units facilitates the procedure, increases 
Ferlengez et al. Non-operating Room Anaesthesia Practices in Endoscopy

patient safety and satisfaction as well as physician comfort. NORA applications are similar to the applications in the operating room due to the risks they carry, but in these places more attention should be paid because the patient circulation is very fast. Under suitable conditions, an experienced anesthesiologist with adequate equipment will be able to safely perform NORA procedures. Today, the number of NORA applications has increased. Anesthesiologists should make a sufficient preoperative evaluation of these patients and try to provide appropriate physical conditions in these departments.

\section{Ethics}

Ethics Committee Approval: Ethics Committee approval was obtained from University of Health Science Turkey, İstanbul Training and Research Hospital for the study (approval no: 1796, date: 12.04.2019).

Informed Consent: Patient information was scanned retrospectively from the anesthesia files; therefore, written consent could not be obtained from the patients for our study.

Peer-review: Externally peer-reviewed.

Authorship Contributions: Surgical and Medical Practices - A.G.F., E.Ç., D.D.A.; Concept - A.G.F., E.Ç., D.D.A.; Design - A.G.F., E.Ç., D.D.A.; Data Collection or Processing - A.G.F., E.C.., D.D.A.; Analysis or Interpretation A.G.F., E.Ç., D.D.A.; Literature Search - A.G.F., E.C.., D.D.A.; Writing - A.G.F., E.C.., D.D.A.

Conflict of Interest: No conflict of interest was declared by the authors.

Financial Disclosure: The authors declared that this study received no financial support.

\section{References}

1. Türk Anesteziyoloji ve Reanimasyon Derneği (TARD). Anestezi Uygulama Klavuzları. Ameliyathane Dıșı Anestezi Uygulamaları. 2015; Aralık.

2. Thompson AM, Wright DJ, Murray W, Ritchie GL, Burton HD, Stonebridge PA. Analysis of 153 deaths after upper gastrointestinal endoscopy: room for improvement? Surg Endosc 2004; 18: 22-5.

3. Vargo JJ, DeLegge MH, Feld AD, Gerstenberger PD, Kwo PY, Lightdale JR, et al. American Association for Study of Liver Diseases, American College of Gastroenterology, American Gastroenterological Association Institute. Multisociety sedation curriculum for gastrointestinal endoscopy. Gastrointest Endosc 2012; 76: e1-e25.

4. Karamnov S, Sarkisian N, Grammer R, Gross WL, Urman RD. Analysis of adverse events associated with adult moderate procedural sedation outside the operating room. J Patient Saf 2017; 13: 111-21.

5. Cima RR, Brown MJ, Hebl JR, Moore R, Rogers JC, Kollengode A, et al. Use of lean and six sigma methodology to improve operating room efficiency in a high-volume tertiary-care academic medical center. J Am Coll Surg 2011; 213: 83-92.

6. Harnett MJ, Correll DJ, Hurwitz S, Bader AM, Hepner DL. Improving efficiency and patient satisfaction in a tertiary teaching hospital preoperative clinic. Anesthesiology 2010; 112: 66-72.

7. Bonnet F, Marret E. Anaesthesia outside the operating room: conflicting strategies? Curr Opin Anaesthesiol 2008; 21: 478-9.

8. Ameliyathane Dışında Anestezi. Tüzüner F, editor. Anestezi Yoğun Bakım Ağrı 1st ed. Ankara: MN Medikal ve Nobel Tıp Kitap Sarayı; 2010.p.1127-36.
9. Kayhan Z. Anestezi ve ameliyat öncesi değerlendirme ve hazırlık. Klinik Anestezi. 3rd ed. İstanbul: Logos Yayıncllık; 2007.p.16-36.

10. Korkmaz T, Ateș Y. Ameliyathane dıșı anestezi uygulamaları. Editörler: Özatamer O, Alkış N, Batıislam Y, Küçük. Anestezide Güncel Konular. Ankara: Nobel Tıp Kitapevleri; 2002;371-91

11. Paspatis GA, Manolaraki MM, Vardas E, Theodoropoulou A, Chlouverakis G. Deep sedation for endoscopic retrograde cholangiopancreatography: intravenous propofol alone versus intravenous propofol with oral midazolam premedication. Endoscopy 2008; 40: 308-13.

12. Ghisi D, Fanelli A, Tosi M, Nuzzi M, Fanelli G. Monitored anesthesia care Minerva Anestesiol 2005; 71: 533-8.

13. Khutia SK, Mandal MC, Das S, Basu SR. Intravenous infusion of ketaminepropofol can be an alternative to intravenous infusion of fentanyl-propofol for deep sedation and analgesia in paediatric patients undergoing emergency short surgical procedures. Indian J Anaesth 2012; 56: 145-50.

14. Roseveare C, Seavell C, Patel P, Criswell J, Shepherd H. Patient-controlled sedation with propofol and alfentanil during colonoscopy: a pilot study. Endoscopy 1998; 30: 482-3.

15. Külling D, Fantin AC, Biro P, Bauerfeind P, Fried M. Safer colonoscopy with patient-controlled analgesia and sedation with propofol and alfentanil. Gastrointest Endosc 2001; 54: 1-7.

16. Poulos JE, Kalogerinis PT, Caudle JN. Propofol compared with combination propofol or midazolam/fentanyl for endoscopy in a community setting. AANA J 2013; 81: 31-6.

17. Horiuchi A, Nakayama Y, Kajiyama M, Kato N, Kamijima T, Ichise Y, et al. Safety and effectiveness of propofol sedation during and after outpatient colonoscopy. World J Gastroenterol 2012; 18: 3420-5.

18. McQuaid KR, Laine L. A systematic review and meta-analysis of randomized, controlled trials of moderate sedation for routine endoscopic procedures. Gastrointest Endosc 2008; 67: 910-23.

19. Türk HŞ, Aybey F, Ünsal O, Açık ME, Ediz N, Oba S. Ameliyathane dıșı anestez deneyimlerimiz. Şş̧li Etfal Hastanesi Tıp Bülteni, 2013; 47: 5-10.

20. İyilikci L, Çakmak S, Ögdül E. Ameliyathane dışı anestezi uygulamalarında deneyimlerimiz. Türk Anest Rean Der Dergisi 2006; 34: 169-76.

21. Cooper GS, Kou TD, Rex DK. Complications following colonoscopy with anesthesia assistance: A population-based analysis. JAMA Intern Med 2013; 173: 551-6.

22. Melloni C. Morbidity and mortality related to anesthesia outside the operating room. Minerva Anestesiol 2005; 71: 325-34

23. Missant C, Van de Velde M. Morbidity and mortality related to anaesthesia outside the operating room. Curr Opin Anaesthesiol 2004; 17: 323-7.

24. Metzner J, Posner KL, Domino KB. The risk and safety of anesthesia at remote locations: the US closed claims analysis. Curr Opin Anesthesiol 2009; 22: 502 8.

25. Amornyotin S. Sedation-related complications in gastrointestinal endoscopy World J Gastrointest Endosc 2013; 5: 527-33.

26. Metzner J, Domino KB. Risks of anesthesia or sedation outside the operating room: the role of the anesthesia care provider. Curr Opin Anaesthesiol 2010 23: 523-31

27. Pino RM. The nature of anesthesia and procedural sedation outside of the operating room. Curr Opin Anaesthesiol 2007; 20: 293-394.

28. Amornyotin S. Sedation-related complications in gastrointestinal endoscopy World J Gastrointest Endosc 2013; 5: 527-33. 